\title{
BEHAVIOUR OF A SEX-DIFFERENTIAL FERTILITY GENE IN HERMAPHRODITE POPULATIONS
}

\author{
M. D. ROSS \\ Grasslands Division, DSIR, Palmerston North, New Zealand
}

Received 21.vi.76

\begin{abstract}
Summary
In genera of flowering plants that contain closely related gynodioecious and near dioecious species, near dioecy has probably evolved from gynodioecy by gradual reduction of seed set on hermaphrodites, caused by the action of several genes for partial female sterility. A literature survey shows that several types of sex-function differential fertility effects are widespread in hermaphrodite plants, so that a model of such variation may be of interest both as a model of normal hermaphrodite populations, and for the above evolutionary process. Such a model is presented where there is a dominant or nondominant gene $P$ for partial female sterility (ovule fertility values $w_{3}, w_{5}<1$ ), and where partially female-sterile hermaphrodites ("subhermaphrodites") may be maintained by overdominance for pollen fertility (homozygote pollen fertility value $\left.w_{4}<1\right)$. Subhermaphrodites have genotypes $P P$ or $P p$, and hermaphrodites have $p p$. Fitness values (numbers of offspring per individual) depend upon genotype frequencies and degree of selfing, so that these values have to be distinguished from the constant fertility or selection values (the $w$ values). Proportions of offspring left through the ovules differ among genotypes, are frequency dependent and differ from those left through the pollen. Outcrossing rates for pollen, $t_{2}$, are also frequency dependent, differ among genotypes and differ from the ovule outcrossing rate, $t_{1}$. For $t_{1} \neq 1, t_{2}$ for hermaphrodites $<t_{1}$, and for $0<t_{1}<1$ and $0<w$ 's $<1$, this $t_{2}$ is less than those for subhermaphrodites, which may be $>t_{1}$. Numerical results are given for equilibrium populations and include some cases of complete female sterility for comparison. These results show that frequencies of subhermaphrodites decrease with increased selfing. The heterozygous subhermaphrodite is the fittest, and the homozygous subhermaphrodite the least fit genotype. The fitness of the heterozygous subhermaphrodite decreases, and that of the hermaphrodite increases, with increased selfing. Except for males, proportions of ovule offspring decrease with increased selfing, and again with this exception and with $t_{1} \neq 1, t_{2}$ is highest for heterozygous subhermaphrodites, and for this type is $>t_{1}$, whereas $t_{2}$ is least for hermaphrodites. The total ovule production of the population increases, and total pollen production decreases, with increased selfing.
\end{abstract}

\section{INTRODUGTION}

Darwin (1877) studied the possible functions and evolution of unisexuality in flowering plants. He recognised gynodioecy, in which some plants were female and others hermaphrodite, together with dioecy and several other conditions, and the gynodioecious examples considered showed little tendency towards dioecy. Since that time, however, a considerable amount of evidence linking the two breeding systems has been obtained, e.g. in several Hawaiian genera (Carlquist, 1966), in Pimelea (Burrows, 1960, 1962; Ross, 1970), in New Zealand Umbelliferae (Lloyd, 1973) and in Mexican species of Fuchsia (Kalin Arroyo and Raven, 1975). Some of these groups contain closely related dioecious and gynodioecious species, and it appears that dioecy has evolved from gynodioecy by gradual reduction of seed set on hermaphrodites. 
Such evolution probably requires several genes for partial female sterility (Ross and Weir, 1976), and these genes require some mechanism for their maintenance, such as differential viability or fertility, or some form of heterosis.

In populations which contain hermaphrodites and have any gene which affects ovule and pollen fertility differentially, of which gynodioecious populations are one extreme example, fitness values (numbers of offspring per individual) are frequency dependent, and have to be distinguished from selection values, which may be taken as constant. Hermaphrodites do not function equally as ovule and as pollen parents, and the degrees of such functioning are frequency dependent. Pollen outcrossing rates, also frequency dependent, may differ among genotypes and differ from ovule outcrossing rates (Lloyd, I974a, 1974b, 1975; Ross and Weir, 1975, 1976; Ross, 1977). Such differential outcrossing rates have been found in experimental populations of the hermaphrodite species Lupinus nanus and Phaseolus lunatus. Both species also showed great variation in male gametophyte selection values (Harding and Tucker, 1969; Horovitz and Harding, 1972). It would be expected a priori that hermaphrodite populations should show variation for fertility, and that such variation should often affect ovules and pollen differentially.

The aims of this paper are: (1) to show that there is abundant evidence for a virtual continuum of inherited sex-function differential fertility effects, and (2) to consider the behaviour in hermaphrodite populations of a gene for partial female sterility, because of its importance both for understanding hermaphrodite populations and for the evolution of dioecy from gynodioecy.

\section{Differential fertility effects}

The aim of this section is not to provide a complete review-there are several hundred publications dealing with male sterility alone-but to give sufficient evidence to demonstrate the biological validity of the accompanying model. We first consider examples of complete male or female sterility where, at least by implication, the fertility of the opposite sex function is largely unimpaired. We then consider complete male sterility but with reduced or increased ovule fertility. Third, we consider partial male or female sterility with no known effects on the fertility of the opposite sex function, and finally we consider the reduced fertility of one sex function accornpanied by a differentially reduced fertility in the other.

The definition of male sterility implies that there is at least partial female fertility (see Jain, 1959, for a review). Many authors state that female fertility is " normal" or " unimpaired", but few have reported on it in detail. A careful study of nine non-allelic recessive male-sterile tomato mutants (Rick, 1948) showed that most of these had a slight tendency towards ovule sterility, although in only one $\left(m s_{8}\right)$ was ovule fertility significantly less than normal ( 75 per cent $v .97$ per cent). Other similar cases are considered below, but it appears that many genes for complete male sterility have relatively slight effects on ovule fertility. This may merely reffect the definition of male sterility. Complete male sterility with normal female fertility also frequently occurs as a result of gene-cytoplasm interactions in hybrids. The classic example of such interactions is in Epilobium. The $\mathrm{F}_{1}$ hybrid $E$. luteum $\times E$. hirsutum showed partial male sterility, and was 
backcrossed using pollen of E. hirsutum. The progeny was backcrossed in the same way, and so on generation by generation. By the sixth generation the offspring were almost identical to $E$. hirsutum, except that most plants were male sterile (Michaelis, 1929; review by Edwardson, 1970). Similar results were obtained in Streptocarpus, e.g. in the $\mathrm{F}_{1}$ of $S$. wendlandii $\times S$. rexii (Oehlkers, 1964, and earlier). This Streptocarpus cross is particularly interesting because the reciprocal cross was male fertile but had a high degree of female sterility, which was increased by backcrossing. Many other examples could be given, also from intraspecific crosses (Edwardson, 1970).

In contrast to the many genes known to cause male sterility, e.g. more than 37 genes in tomato alone (Clayberg et al., 1966), only few reports of genes for female sterility are available. One such gene was found in Rubus idaeus (Crane and Lawrence, 1931), and in tomato genes fms (female sterile) and lyr (lyrate) have the same effect (Glayberg et al., 1966), as do sk (silkless) and $b a$ (barren stalk) in maize (Emerson, Beadle and Fraser, 1935).

A case of complete male sterility accompanied by reduced ovule fertility was already mentioned above (gene $m s_{8}$ in tomato). Another case in tomato is $s l^{2}$ (stamenless), where fruit set is poor on crossing (Clayberg et al., 1966). In barley the gene sc (short chromosome) gives male sterility, but 14.5 per cent of florets set fruit on crossing (Moh and Nilan, 1954), and a similar result was found for the gene mo for multiovary (Moh and Nilan, 1953). In contrast to the reduced female fertility of some male-sterile mutants, females of gynodioecious species sometimes show greater seed fertility than the hermaphrodites (Darwin, 1877). In the gynodioecious Origanum vulgare females set 89 per cent of the maximum possible seed compared with 75 per cent for the hermaphrodites (Lewis and Crowe, 1956). Hybrids may also show complete male and partial female sterility, e.g. in Hypericum acutum $\times H$. montanum (Noack, 1932), and in some individuals of the cross Lotus pedunculatus $\times$ L. tenuis (unpublished results of M. D. Ross and W. T. Jones). Plants having the genome of Triticum vulgare in the cytoplasm of Aegilops caudata are male sterile, but partly female fertile (Kihara, 1962), and when the genome is that of Triticum durum the plants are male sterile but 10 per cent seed fertile (Kihara and Tsunewaki, 1962). Lactuca sativa $\times$ L. serriola is male sterile but sets a fair number of seeds after crossing (Lindqvist, 1960).

Genes for partial male sterility are sometimes reported, although such reports are much less frequent than those for complete or nearly complete male sterility. However, this frequency difference may well be unrelated to any differences in frequency of occurrence of the two types of mutation in nature. Genes for complete male sterility are easily detected, e.g. by failure of fruit set in inbreeders such as tomato (Rick, 1948), and such genes are, moreover, actively sought by plant breeders because of their use in producing hybrid seed. In addition genes for partial male sterility may be avoided by geneticists because of difficulties in classifying progenies. The gradation between genes for complete and for partial male sterility is well illustrated in some environmentally sensitive male-sterility mutations. In male-sterile onions (Allium cepa) no pollen from plants grown at temperatures below $70^{\circ} \mathrm{F}$ appeared viable, but a fraction of 1 per cent appeared viable and some grains germinated when plants were grown at temperatures between $70^{\circ}$ and $80^{\circ} \mathrm{F}$ (Barham and Munger, 1950). In contrast in malesterile Lima beans (Phaseolus lunatus) a high degree of sterility apparently coincided with high temperatures, and in California in September and 
October up to 50 per cent good pollen with anther dehiscence was obtained (Allard, 1953). In sugar beet (Beta vulgaris) offspring of male steriles were classified into 10 male-fertility classes, some of which showed partial male sterility (Oldemeyer, 1957). In sorghum (Sorghum vulgare) $\mathrm{F}_{2}$ and backcross data showed a continuous range of pollen fertility from zero to 100 per cent (Pi and Wuu, 1963). Environmentally sensitive genes for partial male sterility occur in maize, and hot conditions are associated with greater sterility (Duvick, 1965), as in Lima beans. In tomato $m s_{5}$ was the only one among 9 non-allelic male-sterile mutants to produce some functional pollen (Rick, 1948), although another has been found since (Clayberg et al., 1966). In maize the dwarf mutations are often functionally partly or largely male sterile since they shed little or no pollen, and pollen lethals found in this species (Emerson, Beadle and Fraser, 1935) and in the apple (Gagnieu, 1951) cause semi-sterility in heterozygous sporophytes. About half the pollen is functional in maize plants heterozygous for the fertility-restorer allele (i.e. male-fertility allele) $R f_{3}$ in the USDA cytoplasm type (Duvick, 1965). Genes for lethal ovules, transmitted by the pollen, are also known, e.g. in maize (Nelson and Clary, 1952). In Medicago sativa partial male sterility is much more frequent than complete male sterility (Childers, 1952), and a similar situation appears to obtain in cotton (Justus and Leinweber, 1960; Justus, Meyer and Roux, 1963). In Vicia faba X-ray photographs of unopened flower buds suggested that outbred plants produced more pollen than inbreds (Drayner, 1959). In the gynodioecious Plantago lanceolata there appears to be almost a continuum in the quantities of pollen produced by hermaphrodites, rendering classification very difficult (Ross, 1969). In other gynodioecious species such as Origanum vulgare (Kheyr-Pour, 1969) and Silene maritima and S. vulgaris (Marsden-Jones and Turrill, 1957) malefertile plants show greatly varying proportions of female flowers, in addition to the hermaphrodite ones. Male-fertile plants with more female flowers are therefore functionally partly male sterile compared to such plants with fewer female flowers, and they require some mechanism for their maintenance in natural populations. Many Umbelliferae are andromonoecious, having male in addition to hermaphrodite flowers. Proportions of male flowers would be expected to vary, so that plants with higher proportions would be functionally partly female sterile with respect to other types. In a gynodioecious population of Gingidia decipiens (Umbelliferae) male-fertile plants had mostly male florets, but also had variable proportions of hermaphrodite ones (Webb, 1976). Such plants therefore show varying degrees of partial female sterility, and since they occur in natural populations they presumably have some mechanism for their maintenance. Plants homozygous for a gene causing exserted stigmas in tomato are also functionally partly female sterile (Rick and Butler, 1956). Minor genes are reported to affect male sterility, e.g. in maize (Briggle, 1956), sorghum (Craigmiles, 1962), Rubus idaeus (Keep, 1964) and Vaccinium angustifolium (Aalders and Hall, 1963), and in the last species such genes affect female sterility also (Hall, Aalders and Wood, 1966). In the subdioecious Euonymus europaeus both female and near-male plants vary in female fertility (Darwin, 1877). We remember that genes for partial female sterility have already been invoked to account for the evolution of dioecy from gynodioecy (Ross and Weir, 1976). An example of such evolution occurs in Pimelea (Burrows, 1960; 1962). P. traversii is gynodioecious and female flowers set about twice as many fruits as hermaphrodite 
ones. This ratio is about $10: 1$ in the subdioecious $P$. prostrata and reaches $20: 1$ in $P$. sericeo-villosa and $P$. oreophila. Genes reducing fruit set in gynodioecious populations would require some mechanism, such as greater pollen fertility, for their maintenance. Evidence for such a mechanism, perhaps resulting from overdominance, is found in the subdioecious Mercurialis annua, where YY homozygotes are nearly pollen sterile (Westergaard, 1958). Such YY types would be homozygous for several genes controlling partial female sterility, in contrast to the heterozygous XY types.

We now consider cases where partial sterility occurs in both sex functions. In cassava (Manihot esculenta) there is great variability in fertility, and male and female fertility seem to vary independently (Jennings, 1963). In tomato genes affecting the number of locules in the fruit (Rick and Butler, 1956), would probably affect ovule and pollen fertility differentially. In all five $F_{2}$ progenies of varietal crosses in Trifolium subterraneum individual plants were found with good seed set and high pollen sterility, and vice versa (Morley, Brock and Davern, 1956). In rye B-chromosomes depressed seed set more than they reduced pollen stainability (Müntzing, 1963). In Gossypium anomalum $\times G$. arboreum fertility was greater on the female than on the male side (Rhyne, 1965), but in Lotus uliginosus $\times L$. corniculatus three hybrid plants were nearly female sterile but male fertile (Bent, 1962). However, hybrid sterility is usually greater in pollen than in ovules (Stebbins, 1958).

I conclude that there is abundant evidence, both experimental and from natural populations, that ovule and pollen fertility may vary considerably and independently.

\section{THE MODEL}

We consider a gene locus $P f s$ where a dominant or non-dominant allele $P$ controls partial female sterility and allele $p$ controls full fertility. Genotypes having allele $P$ are called "subhermaphrodites" (abbreviated subh). We allow allele $P$ to be favoured by overdominance for pollen fertility to give the following scheme:

$\begin{array}{llll}\begin{array}{l}\text { Genotype } \\ \text { Phenotype } \\ \text { designation }\end{array} & P P & P p & p p \\ \begin{array}{c}\text { Ovule, pollen } \\ \text { fertility }\end{array} & \text { subh-1 } & \text { subh-2 } & \text { herm } \\ \begin{array}{c}w_{3}, w_{4} \\ \text { Frequency }\end{array} & p_{1} & w_{5}, 1 & 1, w_{4} \\ \end{array}$

We set $w_{3}, w_{4}$ and $w_{5}$ to be $<1$, and also set $w_{3} \leqq w_{5}$. When $w_{4}<1$ there is overdominance, and the heterozygous subhermaphrodite is more pollen fertile than the hermaphrodite. When $w_{3}=w_{5}$ allele $P$ is dominant, but when $w_{3}<w_{5} P$ is non-dominant. (Selection values $w_{1}$ and $w_{2}$ are used in a separate publication for gynodioecious populations.)

\section{(i) Next-generation frequencies}

Ovules are assumed to be selfed in proportion $s_{1}$ and crossed in proportion $t_{1}$, where $s_{1}+t_{1}=1$. The normalising denominators $D_{o}$ and $D_{p}$ are used, where $D_{o}$ is proportional to the total ovule production of the population 
and equals $w_{3} p_{1}+w_{5} p_{2}+h$, and $D_{p}$ is proportional to the total pollen production and equals $w_{4}\left(p_{1}+h\right)+p_{2}$. When genotype $P P$ is selfed all the offspring in proportion $s_{1} w_{3} p_{1} / D_{0}$ have the parental genotype, and similarly all $s_{1} h / D_{o}$ offspring which result from selfing genotype $p p$ have the parental genotype. When genotype $P p$ is selfed the resulting $s_{1} w_{5} p_{2} / D_{o}$ offspring segregate into the genotypic ratio of $1 P P: 2 P p: 1 p p$. Crossed ovules have the genotypes $P, p$ in proportions $t_{1}\left(w_{3} p_{1}+\frac{1}{2} w_{5} p_{2}\right) / D_{0}$ and $t_{1}\left(\frac{1}{2} w_{5} p_{2}+h\right) / D_{o}$, respectively, whereas the pollen which fertilises these has genotypes $P, p$ in proportions $\left(w_{4} p_{1}+\frac{1}{2} p_{2}\right) / D_{p}$ and $\left(\frac{1}{2} p_{2}+w_{4} h\right) / D_{p}$, respectively. It is assumed that the pollen which takes part in selfing has a negligible effect on the amount available for crossing.

From the above the following next-generation frequencies, denoted by primes, are obtained:

$$
\begin{gathered}
P P: p_{1}^{\prime}=s_{1}\left(w_{3} p_{1}+\frac{1}{4} w_{5} p_{2}\right) / D_{o}+t_{1}\left(w_{3} p_{1}+\frac{1}{2} w_{5} p_{2}\right)\left(w_{4} p_{1}+\frac{1}{2} p_{2}\right) / D_{o} D_{p} \\
P p: p_{2}^{\prime}=\frac{1}{2} s_{1} w_{5} p_{2} / D_{o}+t_{1}\left[\left(w_{3} p_{1}+\frac{1}{2} w_{5} p_{2}\right)\left(\frac{1}{2} p_{2}+w_{4} h\right)\right. \\
\left.+\left(\frac{1}{2} w_{5} p_{2}+h\right)\left(w_{4} p_{1}+\frac{1}{2} p_{2}\right)\right] / D_{o} D_{p} \\
p p: h^{\prime}=s_{1}\left(h+\frac{1}{4} w_{5} p_{2}\right) / D_{o}+t_{1}\left(\frac{1}{2} w_{5} p_{2}+h\right)\left(\frac{1}{2} p_{2}+w_{4} h\right) / D_{o} D_{p} .
\end{gathered}
$$

\section{(ii) Fitness values}

Offspring through ovules and pollen are considered separately and each offspring individual is counted as half an offspring of the ovule parent and half an offspring of the pollen parent (Ross and Weir, 1976). For genotype $P P$ the number of offspring through the ovules is proportional to $w_{3} p_{1} / 2 D_{0}$ and the number through the pollen is proportional to $s_{1} w_{3} p_{1} / 2 D_{0}$ from selfing and to $t_{1} w_{4} p_{1} / 2 D_{p}$ from crossing. The total number of offspring for this genotype is therefore proportional to $p_{1}\left[\left(1+s_{1}\right) w_{3} D_{p}+t_{1} w_{4} D_{o}\right] / 2 D_{o} D_{p}$, and the fitness value, or number of offspring per individual, is obtained by dividing by the (non-zero) genotype frequency. Such fitness values, called " direct" fitnesses, are readily obtained for the other two genotypes, and are given in table 1, together with "standard" fitnesses, obtained by dividing each direct fitness value by that of the hermaphrodite or standard genotype. Since $w_{3} \leqq w_{5}$ and $w_{4}<1$ the fitness value for homozygous subhermaphrodites is less than for heterozygotes. Similarly since $w_{3}<1$ the fitness of the homozygous subhermaphrodites is less than that for the hermaphrodites, so that the former genotype is the least fit of the three.

The number of offspring left through the ovules of any genotype as a proportion of its total offspring is called $w_{h f}$. The fitness calculations readily yield expressions for these quantities, which are different for each genotype and depend upon the ovule outcrossing rate and the population composition (table 1). Lloyd (1974b, 1976) and Ross and Weir (1975, 1976) have found that $w_{h f} \neq 0.5$ in sex-polymorphic populations, and the present results indicate that this is probably the case for hermaphrodite populations also. For all genotypes when $s_{1}=1, w_{h f}=0 \cdot 5$. For the hermaphrodite when $s_{1}=0, w_{h f}>0 \cdot 5$, since $D_{p}+w_{4} D_{0}<2 D_{p}$; consequently $w_{h f}$ may decrease with increased selfing. The numerical results (table 2) show such decreases for all genotypes, provided $w_{3} \neq 0$. It can also be 
Table 1

Fitness values, proportions of offspring left through the ovules, whe, and pollen outcrossing rates, $\mathrm{t}_{2}$

\begin{tabular}{|c|c|c|c|c|}
\hline Genotype & Direct fitness & Standard fitness & $w_{h f}$ & $t_{2}$ \\
\hline \multirow{2}{*}{$P P$} & $\left(1+s_{1}\right) w_{3} D_{p}+t_{1} w_{4} D_{o}$ & $\left(1+s_{1}\right) w_{3} D_{p}+t_{1} w_{4} D_{o}$ & $w_{3} D_{p}$ & $t_{1} w_{4} D_{o}$ \\
\hline & $2 D_{o} D_{p}$ & $\left(1+s_{1}\right) D_{p}+t_{1} w_{4} \overline{D_{o}}$ & $\overline{\left(1+s_{1}\right) w_{3} D_{p}+t_{1} w_{4} D_{o}}$ & $\overline{s_{1} w_{3} D_{p}+t_{1} w_{4} D_{o}}$ \\
\hline \multirow{2}{*}{$P p$} & $\left(1+s_{1}\right) w_{5} D_{p}+t_{1} D_{o}$ & $\left(1+s_{1}\right) w_{5} D_{p}+t_{1} D_{0}$ & $w_{5} D_{p}$ & $t_{1} D_{0}$ \\
\hline & $2 \overline{D_{o} D_{p}}$ & $\overline{\left(1+s_{1}\right) D_{p}+t_{1} w_{4} D_{o}}$ & $\overline{\left(1+s_{1}\right) w_{5} D_{p}+t_{1} D_{o}}$ & $\overline{s_{1} w_{5} D_{p}+\overline{t_{1} D_{o}}}$ \\
\hline \multirow{2}{*}{$p p$} & $\left(1+s_{1}\right) D_{p}+t_{1} w_{4} D_{o}$ & 1 & $D_{p}$ & $t_{1} w_{4} D_{o}$ \\
\hline & $\overline{2 D_{o} D_{p}}$ & & $\overline{\left(1+s_{1}\right) \overline{D_{p}+t_{1} w_{4} D_{o}}}$ & $\overline{s_{1} D_{p}+t_{1} w_{4} D_{o}}$ \\
\hline
\end{tabular}

TABLE 2

Properties of equilibrium populations for the model of hermaphroditism

\begin{tabular}{|c|c|c|c|c|c|c|c|c|c|c|c|}
\hline \multirow[b]{2}{*}{$w_{3}$} & \multirow[b]{2}{*}{$\mathrm{W}_{4}$} & \multirow[b]{2}{*}{$w_{5}$} & \multirow[b]{2}{*}{$t_{1}$} & \multirow[b]{2}{*}{$\begin{array}{c}\text { Geno- } \\
\text { type }\end{array}$} & \multirow[b]{2}{*}{$\begin{array}{l}\text { Genotype } \\
\text { frequency }\end{array}$} & \multicolumn{2}{|c|}{ Genotype fitness } & \multirow[b]{2}{*}{$w_{h f}$} & \multirow[b]{2}{*}{$t_{2}$} & \multirow[b]{2}{*}{$D_{o}$} & \multirow[b]{2}{*}{$D_{p}$} \\
\hline & & & & & & Direct & Standard & & & & \\
\hline \multirow[t]{2}{*}{0.75} & 0.75 & 0.75 & $1 \cdot 0$ & $\begin{array}{l}P P \\
P p\end{array}$ & $\begin{array}{l}0.016 \\
0.226\end{array}$ & $\begin{array}{l}0.864 \\
1.019\end{array}$ & $\begin{array}{l}0.867 \\
1.022\end{array}$ & $\begin{array}{l}0.462 \\
0.392\end{array}$ & $\begin{array}{l}1.000 \\
1.000\end{array}$ & 0.940 & 0.806 \\
\hline & & & & $p p$ & 0.759 & 0.997 & 1.000 & 0.534 & 1.000 & & \\
\hline \multirow[t]{2}{*}{$0 \cdot 75$} & 0.5 & 0.75 & $1 \cdot 0$ & $\begin{array}{l}P P \\
P p\end{array}$ & $\begin{array}{l}0.131 \\
0.467\end{array}$ & $\begin{array}{l}0.782 \\
1.123\end{array}$ & $\begin{array}{l}0.842 \\
1 \cdot 209\end{array}$ & $\begin{array}{l}0.564 \\
0.393\end{array}$ & $\begin{array}{l}1.000 \\
1.000\end{array}$ & 0.850 & 0.734 \\
\hline & & & & $p p$ & 0.402 & 0.929 & 1.000 & 0.633 & 1.000 & & \\
\hline \multirow[t]{2}{*}{0.75} & 0.5 & 0.75 & $0 \cdot 75$ & $\begin{array}{l}P P \\
P P \\
P p\end{array}$ & $\begin{array}{l}0.072 \\
0.309\end{array}$ & $\begin{array}{l}0.805 \\
1.091\end{array}$ & $\begin{array}{l}0.823 \\
1.116\end{array}$ & $\begin{array}{l}0.515 \\
0.380\end{array}$ & $\begin{array}{l}0.734 \\
0.847\end{array}$ & 0.905 & 0.655 \\
\hline & & & & $p p$ & 0.619 & 0.977 & 1.000 & 0.566 & 0.675 & & \\
\hline \multirow[t]{2}{*}{0.75} & 0.5 & 0.75 & 0.5 & $\begin{array}{l}P P \\
P p\end{array}$ & $\begin{array}{l}0.002 \\
0.011\end{array}$ & $\begin{array}{l}0.812 \\
1.059\end{array}$ & $\begin{array}{l}0.812 \\
1.059\end{array}$ & $\begin{array}{l}0.464 \\
0.355\end{array}$ & $\begin{array}{l}0.568 \\
0.724\end{array}$ & 0.997 & 0.506 \\
\hline & & & & $p p$ & 0.987 & 1.000 * & 1.000 & 0.502 & 0.496 & & \\
\hline \multirow[t]{2}{*}{0.5} & 0.5 & 0.5 & $1 \cdot 0$ & $\begin{array}{l}P P \\
P p\end{array}$ & $\begin{array}{l}0.031 \\
0.319\end{array}$ & $\begin{array}{l}0.682 \\
1.061\end{array}$ & $\begin{array}{l}0.692 \\
1.077\end{array}$ & $\begin{array}{l}0.444 \\
0.286\end{array}$ & $\begin{array}{l}1.000 \\
1.000\end{array}$ & $0 \cdot 825$ & 0.660 \\
\hline & & & & $p p$ & 0.650 & 0.985 & 1.000 & 0.615 & 1.000 & & \\
\hline \multirow[t]{2}{*}{0.5} & 0.5 & 0.5 & 0.75 & $\begin{array}{l}P P \\
P p\end{array}$ & $\begin{array}{l}0.003 \\
0.055\end{array}$ & $\begin{array}{l}0.677 \\
1.033\end{array}$ & $\begin{array}{l}0.678 \\
1.034\end{array}$ & $\begin{array}{l}0.380 \\
0.249\end{array}$ & $\begin{array}{l}0.847 \\
0.917\end{array}$ & 0.971 & 0.528 \\
\hline & & & & $p p$ & 0.942 & 0.999 & 1.000 & 0.515 & 0.734 & & \\
\hline \multirow[t]{2}{*}{0.5} & 0.75 & 0.75 & $1 \cdot 0$ & $\begin{array}{l}P P \\
P p\end{array}$ & $\begin{array}{l}0.008 \\
0.165\end{array}$ & $\begin{array}{l}0.736 \\
1.025\end{array}$ & $\begin{array}{l}0.738 \\
1.027\end{array}$ & $\begin{array}{l}0.356 \\
0.383\end{array}$ & $\begin{array}{l}1.000 \\
1.000\end{array}$ & 0.955 & 0.791 \\
\hline & & & & $p p$ & 0.827 & 0.998 & 1.000 & 0.525 & 1.000 & & \\
\hline \multirow[t]{2}{*}{0.5} & 0.5 & 0.75 & $1 \cdot 0$ & $\begin{array}{l}P P \\
P p\end{array}$ & $\begin{array}{l}0.085 \\
0.426\end{array}$ & $\begin{array}{l}0.644 \\
1.142\end{array}$ & $\begin{array}{l}0.687 \\
1.217\end{array}$ & $\begin{array}{l}0.456 \\
0.386\end{array}$ & $\begin{array}{l}1.000 \\
1.000\end{array}$ & 0.851 & 0.713 \\
\hline & & & & $p p$ & 0.489 & 0.938 & 1.000 & 0.626 & 1.000 & & \\
\hline \multirow[t]{2}{*}{0.5} & 0.5 & 0.75 & 0.75 & $\begin{array}{l}P P \\
P p\end{array}$ & $\begin{array}{l}0.038 \\
0.245\end{array}$ & $\begin{array}{l}0.641 \\
1.112\end{array}$ & $\begin{array}{l}0.654 \\
1.134\end{array}$ & $\begin{array}{l}0.424 \\
0.367\end{array}$ & $\begin{array}{l}0.816 \\
0.855\end{array}$ & 0.920 & 0.622 \\
\hline & & & & $p p$ & 0.717 & 0.981 & 1.000 & 0.554 & 0.689 & & \\
\hline \multirow[t]{2}{*}{0.0} & 0.5 & $0 \cdot 5$ & $1 \cdot 0$ & $P P$ & 0.018 & 0.393 & 0.399 & 0.000 & 1.000 & 0.846 & 0.636 \\
\hline & & & & $P p$ & $\begin{array}{l}0.272 \\
0.710\end{array}$ & 0.984 & $\begin{array}{l}1.099 \\
1.000\end{array}$ & 0.601 & 1.000 & & \\
\hline \multirow[t]{3}{*}{0.0} & 0.5 & 0.5 & 0.75 & $P P$ & 0.001 & 0.365 & 0.365 & 0.000 & 1.000 & 0.985 & 0.514 \\
\hline & & & & $P p$ & 0.028 & 1.047 & 1.048 & 0.242 & 0.920 & & \\
\hline & & & & $p p$ & 0.971 & 0.999 & 1.000 & 0.508 & 0.742 & & \\
\hline
\end{tabular}

shown, by simple inequalities, that $w_{h f}$ is less for all subhermaphrodites than for hermaphrodites, as would be expected. For example, since

$$
\begin{aligned}
w_{5}\left[\left(1+s_{1}\right) D_{p}+t_{1} w_{4} D_{o}\right] & <\left(1+s_{1}\right) w_{5} D_{p}+t_{1} D_{o}, \\
& w_{5} D_{p} /\left[\left(1+s_{1}\right) w_{5} D_{p}+t_{1} D_{o}\right]<D_{p} /\left[\left(1+s_{1}\right) D_{p}+t_{1} w_{4} D_{o}\right] .
\end{aligned}
$$

For dominant $P, w_{3}=w_{5}$, $w_{h f}$ for genotype $P p$ is less than for $P P$.

\section{(iii) Outcrossing rates}

The pollen outcrossing rate of a genotype is called $t_{2}$, and differs from that for the ovules in all populations containing hermaphrodites and having 
a sex-differential fertility gene (Ross, 1977). For genotype $P P$ the proportion of pollen which takes part in crossing is $t_{1} w_{4} p_{1} / D_{p}$, and that which takes part in selfing is $s_{1} w_{3} p_{1} / D_{o}$, so that $t_{2}$ for this genotype equals

$$
t_{1} w_{4} D_{o} /\left(s_{1} w_{3} D_{p}+t_{1} w_{4} D_{o}\right) \text {. }
$$

This result and similar results for the other genotypes (table l) show that $t_{2}$ always differs from $t_{1}$, differs also among genotypes and varies with the population composition. The following results apply when all genotypes are present. For a dominant gene, $w_{3}=w_{5}$, and for $0<t_{1}<1, t_{2}$ for the heterozygous subhermaphrodite, $P p$, is greater than $t_{1}$ if

$$
t_{1} D_{o} /\left(s_{1} w_{5} D_{p}+t_{1} D_{o}\right)>t_{1} .
$$

This inequality holds since $w_{4}<1$, so that

$$
w_{5}\left(p_{1}+h\right)>w_{4} w_{5}\left(p_{1}+h\right), w_{5}\left(p_{1}+p_{2}\right)+h>w_{5}\left[w_{4}\left(p_{1}+h\right)+p_{2}\right],
$$

i.e. $D_{o}>w_{5} D_{p}, D_{o}\left(1-t_{1}\right)>s_{1} w_{5} D_{p}, D_{o}>s_{1} w_{5} D_{p}+t_{1} D_{o}, D_{o} /\left(s_{1} w_{5} D_{p}+t_{1} D_{o}\right)>1$ and $t_{1} D_{o} /\left(s_{1} w_{5} D_{p}+t_{1} D_{o}\right)>t_{1}$. Similarly it is easily shown that if $t_{1} \neq 1, t_{2}$ for the hermaphrodite, $p p$, is always less than $t_{1}$, i.e. that

$$
t_{1} w_{4} D_{o} /\left(s_{1} D_{p}+t_{1} w_{4} D_{o}\right)<t_{1} .
$$

This is so since $w_{4}\left(w_{3} p_{1}+w_{5} p_{2}+h\right)<w_{4}\left(p_{1}+h\right)+p_{2}$, i.e. $w_{4} D_{o}<D_{p}$. Consequently $w_{4} D_{o}\left(1-t_{1}\right)<s_{1} D_{p}, w_{4} D_{o}<s_{1} D_{p}+t_{1} w_{4} D_{o}$ and

$$
t_{1} w_{4} D_{o} /\left(s_{1} D_{p}+t_{1} w_{4} D_{o}\right)<t_{1} \text {. }
$$

Numerical results (below) show that $t_{2}$ for the homozygous subhermaphrodite, genotype $P P$, may be greater or less than $t_{1}$. It is also easily seen that when $t_{1}$ and the various $w$ 's are between 0 and $1, t_{2}$ for the hermaphrodite is less than for either subhermaphrodite, i.e. that $t_{1} w_{4} D_{o} /\left(s_{1} D_{p}+t_{1} w_{4} D_{o}\right)$ is less than $t_{1} w_{4} D_{o} /\left(s_{1} w_{3} D_{p}+t_{1} w_{4} D_{o}\right)$ and less than $t_{1} D_{o} /\left(s_{1} w_{5} D_{p}+t_{1} D_{o}\right)$. The first inequality is seen by inspection since $w_{3}<1$. The second inequality holds since $w_{4} w_{5}<1$, so that

$$
\begin{gathered}
s_{1} w_{4} w_{5} D_{p}<s_{1} D_{p}, w_{4}\left(s_{1} w_{5} D_{p}+t_{1} D_{o}\right)<s_{1} D_{p}+t_{1} w_{4} D_{o}, \\
w_{4} /\left(s_{1} D_{p}+t_{1} w_{4} D_{o}\right)<1 /\left(s_{1} w_{5} D_{p}+t_{1} D_{o}\right) \text { and } \\
t_{1} w_{4} D_{o} /\left(s_{1} D_{p}+t_{1} w_{4} D_{o}\right)<t_{1} D_{o} /\left(s_{1} w_{5} D_{p}+t_{1} D_{o}\right) .
\end{gathered}
$$

For a dominant gene, $w_{3}=w_{5}$, it can also be shown that $t_{2}$ for the homozygous subhermaphrodite is less than that for the heterozygote, since

$$
\begin{gathered}
w_{4}\left(s_{1} w_{5} D_{p}\right)<s_{1} w_{5} D_{p}, w_{4}\left(s_{1} w_{5} D_{p}+t_{1} D_{o}\right)<s_{1} w_{5} D_{p}+t_{1} w_{4} D_{o} \\
w_{4} /\left(s_{1} w_{5} D_{p}+t_{1} w_{4} D_{o}\right)<1 /\left(s_{1} w_{5} D_{p}+t_{1} D_{o}\right) \text { and } \\
t_{1} w_{4} D_{o} /\left(s_{1} w_{5} D_{p}+t_{1} w_{4} D_{o}\right)<t_{1} D_{o} /\left(s_{1} w_{5} D_{p}+t_{1} D_{o}\right) .
\end{gathered}
$$

\section{(iv) Numerical results}

Numerical results were obtained by repeated substitutions in the genotype frequency transition equations. Table 2 gives results only for those populations with subhermaphrodites present. For each set of w's computer runs were made with $t_{1}$ equal to $1 \cdot 0,0.75$ and 0.5 , so that the presentation of less than three sets of results for any set of $w$ 's implies that subhermaphrodites were missing at equilibrium in the omitted populations. Subherma- 
phrodites were also not present at equilibrium when $w_{5}$ was less than $w_{4}$, as might be expected. The last two populations in the table have $w_{3}=0$, implying that genotype $P P$ is male. It is not intended to suggest that males arose in nature in this fashion, but rather to give an extreme case for comparison with less extreme ones.

In the first six populations of the table gene $P$ is dominant since $w_{3}=w_{5}$, whereas the remaining five populations have non-dominant $P$. We may take the first population to represent those having a moderate degree of female sterility $\left(w_{3}=w_{5}=0.75\right)$ and overdominance $\left(w_{4}=0.75\right)$. We note that about 24 per cent of subhermaphrodites are present when mating is at random, but that these are lost as soon as the selfing rate reaches 0.25 or more. The other results show that proportions of subhermaphrodites decline with increased selfing throughout the table and a greater degree of overdominance than in the first population $\left(w_{4}=0.5\right)$ is required to maintain them with selfing rates of 0.25 or 0.5 .

We now consider the fitness and outcrossing characteristics of the model. For all populations in table 2 the equilibrium fitness of the heterozygous subhermaphrodite (subhermaphrodite-2 is greater than one, and greater than that of the hermaphrodite, which always has a direct fitness of less than one. The table confirms that the fitness of the homozygous subhermaphrodite (subhermaphrodite-1) is always least. With increased selfing the equilibrium fitness of subhermaphrodite- 2 decreases despite its decreased equilibrium frequency, whereas that of the hermaphrodite increases despite its increased frequency. The fitness of subhermaphrodite-1 may decrease or increase. The proportion of offspring left through the ovules, $w_{h f}$, is less than 0.5 for subhermaphrodite- 2 and more than 0.5 for the hermaphrodite, as might be expected, but for subhermaphrodite-1 this proportion may be greater or less than 0.5 , depending in part on $t_{1}$. Although the heterozygous subhermaphrodite in the sixth population in the table is half as ovule fertile as the hermaphrodite, it leaves only about a quarter of its offspring through the ovules. Non-zero values for $w_{h f}$ decrease with increased selfing. When the ovule outcrossing rate, $t_{1}$, is less than one, the pollen outcrossing rate, $t_{2}$, is greater than $t_{1}$ for subhermaphrodite-2 and less than $t_{1}$ for the hermaphrodite, as demonstrated above, but for subhermaphrodite-1 $t_{2}$ may be greater than, less than or (in the special case of $w_{3}=0$ ) equal to $t_{1}$. For $t_{1} \neq 1$ and $w_{3} \neq 0$ in the table subhermaphrodite- 2 has the greatest value for $t_{2}$, followed by subhermaphrodite-1 and with the hermaphrodite last.

Table 2 also gives $D_{o}$, the total population ovule or seed production, and $D_{p}$, the total pollen production. $D_{o}$ increases and $D_{p}$ decreases, with increased selfing. With a heterotic species the increased homozygosity resulting from increased selfing may therefore result in the production by the population of more seed, but of a lower quality. Such a strategy may be advantageous in some circumstances.

\section{Discussion}

From the simple assumptions that hermaphrodite populations are likely to show genetic variability for fertility and that variant genotypes will often show unequal effects in each sex function, it follows that fitness values (numbers of offspring per individual) must be distinguished from the selection or fertility values, that fitness values are not constant but vary 
with the population composition and that pollen outcrossing rates differ from those for ovules and differ among genotypes. The extent to which individuals function as ovule and as pollen parents also differs among genotypes and varies with the population composition. Since there is increasing evidence that selection values are themselves frequency dependent (e.g. Petit and Ehrman, 1969) we must expect hermaphrodite populations to show a complex form of frequency-dependent fitness.

The model can be taken as representing normal genetic variability for fertility in moderately to largely outcrossing hermaphrodite populations. Ross and Weir (1976) have suggested that dioecy or subdioecy with male heterogamety evolves when recessive genes for male sterility become completely linked with dominant or non-dominant genes for partial female sterility. The male-steriles interact with the less ovule-fertile but more pollen-fertile hermaphrodites until ultimately the breeding system is essentially dioecious. Unpublished results of a model with one gene for male sterility and for one partial female sterility show that even for free recombination there may be more male-steriles at equilibrium for the digenic model, than for one of monogenic recessive gynodioecy with equivalent selection values, provided there is some selfing. Linkage gives more subhermaphrodites and females, but reduced frequencies of hermaphrodites. With complete linkage all partially female-sterile females and some subhermaphrodite types are eliminated, and for sufficiently great selection differentials hermaphrodites also are eliminated. Additional genes of both types would be expected to become completely linked to the first two, resulting in a multilocus type of subdioecy.

Acknowledgments.-Dr D. G. Lloyd and Dr B. S. Weir commented on an earlier draft of the manuscript.

\section{References}

AALDERS, L. E., AND HALL, 1. V. 1963. The inheritance and morphological development of male-sterility in the common lowbush blueberry, Vaccinium angustifolium Ait. Can. $\mathcal{F}$. Genet. Cytol., 5, 380-383.

ALLARD, R. W. 1953. A gene in Lima beans pleiotropically affecting male-sterility and seedling abnormality. Proc. Amer. Soc. Hort. Sci., 61, 467-471.

barham, w. s., And munger, H. M. 1950. Stability of male sterility in onions. Proc. Amer. Soc. Hort. Sci., 56, 401-409.

BENT, F. G. 1962. Interspecific hybridisation in the genus Lotus. Can. 7. Genet. Cytol., 4, 15l-159.

BRIGGLE, L. W. 1956. Interaction of cytoplasm and genes in male-sterile corn crosses involving two inbred lines. Agron. $7 ., 48,569-573$.

Burrows, G. J. 1960. Studies in Pimelea. I. The breeding system. Trans. Royal Soc. New Zealand, $88,29-45$.

Burrows, c. J. 1962. Studies in Pimelea. II. Taxonomy of some mountain species. Trans. Royal Soc. New Zealand, Botany, 1, 217-223.

CARlQuist, S. 1966. The biota of long-distance dispersal. IV. Genetic systems in the floras of oceanic islands. Evolution, 20, 433-455.

Ghilders, w. R. 1952. Male sterility in Medicago sativa L. Sci. Agric., 32, 351-364.

CLAYBERG, G. D., BUTLER, L., KERR, E. A., RICK, C. M., AND ROBINSON, R. w. 1966. Third list of known genes in the tomato. F. Hered., 57, 188-196.

Graigmiles, J. P. 1962. Genetic inheritance of cytoplasmic male-sterility in Sudangrass. Crop. Sci., 2, 203-205.

GRANE, M. B., AND LAWRENGE, w. J. G. 1931. Inheritance of sex, colour and hairiness in Rubus ideaus L. 7. Genet., 24, 243-255.

DARwin, c. 1877. The Different Forms of Flowers on Plants of the Same Species. Murray, London. 
drayner, J. M. 1959. Self- and cross-fertility in field beans (Vicia faba). 7. Agric. Sci., 53, 387-403.

DUvick, D. N. 1965. Cytoplasmic pollen sterility in corn. Adv. Genet., 13, 1-56.

edWArdson, J. R. 1970. Cytoplasmic male sterility. Bot. Rev., 36, 341-420.

EMERSON, R. A., BEADLE, G. W., AND FRASER, A. C. 1935. A summary of linkage studies in maize. Mem. Cornell Univ. Agric. Exp. Sta., 180, 1-83.

Gagnieu, A. 1951. Production de pollen chez le pommier: possibilité de léthalité génique monofactorielle. Ann. Inst. Nat. Rech. Agron. Sér B, 1, 455-496.

HALl, I. V., AALDERS, L. E., AND wOOD, G. W. 1966. Female sterility in the common lowbush blueberry, Vaccinium angustifolium Ait. Can. 7. Genet. Cytol., 8, 296-299.

HARDING, J., AND TUCKER, C. L. 1969. Quantitative studies on mating systems. III. Methods for the estimation of male gametophyte selective values and differential outcrossing rates. Evolution, 23, 85-95.

HOROVITZ, A., AND HARDING, J. 1972. The concept of male outcrossing in hermaphrodite higher plants. Heredity, 29, 223-236.

JAIN, s. K. 1959. Male sterility in flowering plants. Bibliogr. Genet., 18, 101-166.

JENNINGS, D. L. 1963. Variation in pollen and ovule fertility in varieties of cassava, and the effect of interspecific crossing on fertility. Euphytica, 12, 69-76.

JUSTUS, N., AND LEINWEBER, C. L. 1960. A heritable partially male-sterile character in cotton. J. Hered., 51, 191-192.

JUSTUS, N., MEYER, J. R., AND ROUX, J. B. 1963. A partially male-sterile character in upland cotton. Crop Sci., 3, 428-429.

KALIN ARROYO, M. T., AND RAVEN, P. H. 1975. The evolution of subdioecy in morphologically gynodioecious species of Fuchsia sect. Encliandra (Onagraceae). Evolution, 29, 500-511.

KeEP, E. 1964. Sepaloidy in the red raspberry, Rubus idaeus L. Can. 7. Genet. Cytol., 6, $52-60$.

KHEYR-POUR, A. 1969. Contribution à l'étude du déterminisme génétique et écologique du polymorphisme sexuel chez Origanum vulgare L. Compt. Rend. Acad. Sci., 268D, 2566-2568.

kimara, H. 1962. Cytoplasmic male sterility of common wheat. Ann. Rep. Nat. Inst. Genet. Japan, 12, 48-50.

kihara, H., AND TsUnewaki, K. 1962. Pistillody of Triticum durum induced by an Aegilops cytoplasm. Ann. Rep. Nat. Inst. Genet. Japan, 12, 50.

LEWIS, D., AND CROWE, L. K. 1956. The genetics and evolution of gynodioecy. Evolution, 10, 115-125.

LINDQVist, K. 1960. Inheritance studies in lettuce. Hereditas, 46, 387-470.

LLOYD, D. G. 1973. Sex ratios in sexually dimorphic Umbelliferae. Heredity, 31, 239-249.

LLOYD, D. G. 1974a. Theoretical sex ratios of dioecious and gynodioecious Angiosperms. Heredity, 32, 11-34.

LLOYD, D. G. 1974b. The genetic contributions of individual males and females in dioecious and gynodioecious Angiosperms. Heredity, 32, 45-51.

LLOYD, D. G. 1975. The maintenance of gynodioecy and androdioecy in Angiosperms. Genetica, 45, 325-339.

LLOYD, D. G. 1976. The transmission of genes via pollen and ovules in gynodioecious Angiosperms. Theor. Popn. Biol., 9, 299-316.

MARSDEn-JONEs, E. M., AND TURRILl, w. B. 1957. The Bladder Campions. Ray Society, London.

michaelis, P. 1929. Über den Einfluss von Kern und Plasma auf die Vererbung. Biol. Zentralbl., 49, 302-316.

MOH, C. C., AND NILAN, R. A. 1953. Multi-ovary in barley. A mutant induced by atomic bomb irradiation. 7. Hered., 44, 183-184.

MOH, C. C., AND NILAN, R. A. 1954. "Short" chromosome-A mutant in barley induced by atomic bomb irradiation. Cytologia, 19, 48-53.

MORLEY, F. H. W., BROCK, R. D., AND DAVERN, C. I. 1956. Subspeciation in Trifolium subterraneum. Austral. 7. Biol. Sci., 9, 1-17.

MÜNTZING, A. 1963. Effects of accessory chromosomes in diploid and tetraploid rye. Hereditas, 49, 371-426.

NELSON, O. E., JR., AND CLARY, G. B. 1952. Genic control of semi-sterility in maize. $\mathcal{J}$. Hered., 43, 205-210.

NOACK, K. L. 1932. Über Hypericum-kreuzungen. II. Beobachtungen an HypericumArtbastarden, Ber. deut. bot. Ges., 50, 256-268.

oehlkers, F. 1964. Cytoplasmic inheritance in the genus Streptocarpus Lindley. Adv. Genet., 12, 329-370. 
oldemeyer, r. к. 1957. Sugar beet male sterility. 7. Amer. Soc. Sugar Beet Technol., 9, $381-386$.

Petit, c., AND Ehrman, L. 1969. Sexual selection in Drosophila. Evol. Biol., 3, 177-223.

PI, C.-P., AND WUU, K.-D. 1963. The inheritance of cytoplasmic genetic male sterility in sorghum. Bot. Bull. Acad. Sin., 4, 15-22.

RHYNE, C. L. 1965. Cytoplasmic inheritance of reduced androecium in cotton. 7. Hered., $56,67-70$.

RICK, C. M. 1948. Genetics and development of nine male-sterile tomato mutants. Hilgardia, 18, 599-633.

RiCK, C. M., AND BUtler, L. 1956. Cytogenetics of the tomato. Adv. Genet., 8, 267-382.

Ross, м. D. 1969. Digenic inheritance of male sterility in Plantago lanceolata. Can. F. Genet. Cytol., 11, 739-744.

Ross, M. D. 1970. Evolution of dioecy from gynodioecy. Evolution, 24, 827-828.

ROss, M. D. 1977. Frequency-dependent fitness and differential outcrossing rates in hermaphrodite populations. Amer. Natur. (in press).

ROSS, M. D., AND WEIR, B. S. 1975. Maintenance of male sterility in plant populations. III. Mixed selfing and random mating. Heredity, 35, 21-29.

ROSS, M. D., AND WEIR, B. s. 1976. Maintenance of males and females in hermaphrodite populations and the evolution of dioecy. Evolution, 30, 425-441.

stebins, G. L. 1958. The inviability, weakness, and sterility of interspecific hybrids. $A d v$. Genet., 9, 147-215.

WEBB, c. J. 1976. Flowering periods in the gynodioecious species Gingidia decipiens (Umbelliferae). N.Z. F. Bot., 14, 207-210.

WESTERGAARD, M. 1958. The mechanism of sex determination in dioecious flowering plants. Adv. Genet., 9, 217-282. 